\title{
DEMONOLOGIA ANALISADA SOB A ÓPTICA DOS ESCRITOS DO PADRE GABRIELE AMORTH
}

\section{ARTIGO ORIGINAL}

\section{LEITE, Leonardo Delatorre ${ }^{1}$}

LEITE, Leonardo Delatorre. Demonologia analisada sob a óptica dos escritos do Padre Gabriele Amorth. Revista Científica Multidisciplinar Núcleo do Conhecimento. Ano 05, Ed. 08, Vol. 05, pp. 119-145. Agosto de 2020. ISSN: 2448-0959, Link de acesso: https://www.nucleodoconhecimento.com.br/teologia/demonologia

\section{RESUMO}

Os estudos demonológicos estão ganhando cada vez mais destaque no campo de abordagem da dogmática católica, especialmente pela necessidade de um conhecimento teológico mais próximo de uma cosmovisão centrada na Soberania de Deus, na cristologia e nos fundamentos da obra redentora de Jesus enquanto Salvador. O padre Amorth representa um dos principais autores de demonologia, cujos escritos mantêm uma linha de pensamento consonante com as Sagradas Escrituras e com a tradição da Igreja, sempre frisando a ligação dos estudos demonológicos com a obra Redentora de Cristo. Sendo assim, as reflexões deixadas por Amorth representam uma excelente introdução para os principais temas concernentes aos vários aspectos e peculiaridades das ações demoníacas, bem como o problema central referente a relação da demonologia com a teologia espiritual. $O$ respectivo trabalho acadêmico teve como objetivo primordial o estabelecimento de uma relação direta dos estudos concernente aos preceitos da demonologia com a espiritualidade cristã através de uma revisão bibliográfica da vasta obra do Padre Amorth. Ademais, frisou-se a realização de uma abordagem comparativa dos escritos

1 Graduando em Direito e História pela Universidade Presbiteriana Mackenzie. Bolsista PIBIC-CNPq. Membro do grupo de pesquisa "Religião, Memória e Cultura" do CEFT (Centro de Educação, Filosofia e Teologia) da Universidade Mackenzie/SP. 
do padre com os principais concílios ecumênicos da Igreja Católica e também com a teologia sistemática de São Tomás de Aquino. A lição derradeira deixada pelas análises estabelecidas consiste numa importante afirmação: Não há como compreender essencialmente a Redenção cristã sem um conhecimento básico sobre a vocação da Igreja e dos fiéis na batalha espiritual contra a realidade das atividades demoníacas.

Palavras-chave: Demonologia, cristologia, redenção, espiritualidade, batalha espiritual.

\section{INTRODUÇÃO}

A existência do demônio é tida como uma verdade e dogma de fé na doutrina cristã. Desde os primórdios do desenvolvimento da teologia sistemática, as discussões acerca dos anjos e do mundo espiritual já eram extremamente eminentes, contribuindo para evolução de um conhecimento religioso mais próximo da mensagem do Evangelho, das Sagradas escrituras e da Revelação Especial de Deus.

Não obstante a importância teológica do assunto em questão, muitos pensadores intitulados cristãos estão se afastando cada vez da tradição estabelecida sobre a existência do demônio e de suas ações ordinárias e extraordinárias. Sendo assim, se faz extremamente necessário um resgate das doutrinas elementares acerca do assunto supramencionado, e para tal, a perspectiva tomista demonstra um caráter estratégico, porquanto seu conteúdo representa uma verdadeira apologética dos valores e dogmas do cristianismo.

Além do resgate dos escritos tomistas, a demonologia contemporânea tem como grande expoente o Padre Gabriele Amorth (1925-2016), cujas obras apresentam uma explicação sintética e concisa, em conformidade com a teologia sistemática católica e com a doutrina de São Tomás de Aquino, acerca da natureza demoníaca. O padre Amorth foi um grande sacerdote da Pia Sociedade de São Paulo, ordenado em 1954 e nomeado no ano de 1986 como exorcista da Diocese de Roma. É mais conhecido 
por ser fundador e presidente honorário da Associação Internacional dos Exorcistas, além de ter sido um notável membro da Pontifícia Academia Mariana Internacional.

O padre Gabriele tem como ponto de partida os pressupostos contidos na Summa Teológica para promover uma explanação acerca dos anjos e demônios. Por este motivo, os escritos demonológicos do sacerdote em questão representam uma fonte segura de estudo para aqueles que procuram um contato introdutório com o tema, pois as lições deixadas por ele encontram respaldo na filosofia tomista e nos principais concílios ecumênicos da Igreja católica, tais como: IV Concílio de Latrão, Concílio de Trento e Concílio Vaticano I.

Amorth sempre frisou o estudo da demonologia como um instrumento não voltado somente para o conhecimento do maligno, mas, sobretudo, para nutrir um espírito de perseverança e fortaleza contra o Mal. Ademais, vale ressaltar que um melhor esclarecimento acerca da natureza do maligno possibilita uma compreensão profunda sobre a obra redentiva de Cristo bem como de seus ofícios como Rei, profeta e sacerdote.

\section{A EXISTÊNCIA DO DEMÔNIO}

Ora, baseada no testemunho claríssimo das Escrituras, lidas à luz da Tradição, a Igreja sempre creu na existência dos anjos, criaturas espirituais inferiores a Deus, mas superiores aos homens. Trata-se de uma verdade de fé, definida explicitamente por ao menos dois Concílios ecumênicos: o IV de Latrão (DH 800), cujas palavras foram mais tarde repetidas pelo Vaticano I (DH 3002).[2]

A existência dos demônios sempre foi um dogma atestado e confirmado nos principais concílios ecumênicos da Igreja. Portanto, a teologia dogmática histórica é categórica na afirmação de que o demônio existe e age continuamente no mundo. O Padre José Antonio Sayés Bermejo, um dos grandes teólogos da atualidade, desenvolve posições apologéticas para sustentar a afirmação supramencionada, estabelecendo três critérios: a) a múltipla atestação; b) a questão da descontinuidade: o povo de Israel tinha um desejo ardente por um Messias político, que o libertasse da tirania do Império Romano, mas quebrando esta tamanha expectativa, Jesus prega o Reino dos Céus, 
e c) a identidade de Jesus. A múltipla atestação consiste nas inúmeras referências existentes nos Evangelhos que apresentam uma narrativa dos embates de Jesus com o Demônio bem como de muitas passagens do Novo testamento acerca de Satanás.

O termo Satanás ocorre trinta e quatro vezes no Novo Testamento. Metade desses termos encontram-se nos Evangelhos e em Atos, e metade nas Epístolas e no Apocalipse. Todas as referências, com exceção de seis, são "o Satanás". Outros nomes de Satanás, no Novo testamento, incluem o acusador (Ap 12.10); o adversário (1 Pedro 5.8); Apoliom (Ap 9.11); Belzebu (Mt 12.24); Belial (2 Co 6.15); o dragão (...); o deus deste século (2 Co 4.4); o príncipe das potestades do ar (Ef 2.2); o príncipe deste mundo (João 12:31); a serpente (Ap 20.2) e o tentador (Mt. 4.3). (BEEKE, 2018, p.27-28)

O critério da descontinuidade está relacionado com a preocupação de Jesus com o Reino dos Céus e não com questões propriamente políticas e ideológicas. Sendo assim, Cristo demonstrou que seu inimigo não era César, mas Satanás e os demônios. Joachim Jeremias, exegeta protestante, é incisivo ao afirmar que as tentações de Jesus no deserto tendiam ao messianismo político, ou seja, na redução da esfera redentora e salvífica da obra do Filho de Deus ao aspecto das disputas sociais e de poder existentes na época.

A primeira, que propõe transformar pedras em pães, pode ser interpretada como uma tentativa de induzir o Senhor Jesus a ser o "novo Moisés", libertando o povo como Moisés libertou o povo do Egito; a segunda, como receber os reinos do mundo para governar; a terceira, como transformar-se numa espécie de "super-homem", realizando algo fantástico e, então, ser seguido por todos. Todas tentações políticas. Essa espécie de sedução rondou Jesus durante todo o seu ministério, mas Ele sempre resistiu, apresentando o Reino dos Céus como uma realidade espiritual. Portanto, seu inimigo era Satanás e seus demônios, não César. [3]

O critério da identidade de Jesus consiste no reconhecimento de sua obra redentora. O reinado de Deus está intrinsecamente relacionado ao combate contra o Diabo, pois Cristo veio ao mundo para romper a escravidão provocada pelo pecado. Esta realidade é tão nítida no Novo testamento, que se retirada, a própria concepção teológica clássica acerca da cristologia perde sentido e os dogmas relacionados a justificação são prejudicados. Por este motivo, a chamada "desmitologização" do 
Evangelho promovida por Rudolf Bultmann é uma verdadeira negação da fé cristã. A cosmovisão cristã é categórica em afirmar que Jesus combateu a Satanás e seus demônios. Conforme ressalta o padre Mazzali (2017, p.19) , o novo testamento nos fala constantemente da realidade do Diabo e dos demônios e busca mostrar como a obra redentora de Cristo tem como aspecto finalístico a destruição das obras demoníacas. Sendo assim, não é possível compreender a obra salvífica de Jesus Cristo sem considerar a existência do Diabo e de seus demônios.

A teologia cristã entende que o sentido do ensinamento sobre a existência do demônio é revelar que a humanidade se encontra numa história de salvação e condenação. A presença da figura de Satanás, enquanto tentador, é um constante aviso e alerta de que o pecado é uma possibilidade e que a condenação eterna não é meramente uma hipótese distante. Entender os pressupostos da demonologia implica num conhecimento mais estrutural sobre a teologia histórica bem como da relação entre providência de Deus e a liberdade humana. Sobre o assunto, o cardeal Joseph Ratzinger comenta:

A luta espiritual contra os poderes escravizadores, o exorcismo de um mundo iludido por demônios, pertence inseparavelmente ao caminho espiritual de Jesus e ao centro da missão d'Ele mesmo e dos seus discípulos. A figura de Jesus, a sua fisionomia espiritual, não se muda, quer o sol gire ao redor da terra, quer a terra ao redor do sol, quer o mundo tenha se formado por evolução, quer não; mas ela muda decisivamente, se removermos a luta com o poder experimentado do reino dos demônios. (RATZINGER, 1981, p.160)

"Não é possível compreender a obra da Redenção (pela qual Jesus Cristo redimiu a humanidade), se não reconhecer a obra de desagregação realizada por Satanás" (AMORTH, 2013, p.19). Portanto, a existência do demônio tem um aspecto central para estruturação da cosmovisão cristã, especialmente para uma correta compreensão acerca dos pressupostos e nuances da cristologia.

\section{A NATUREZA DE SATANÁS E DOS DEMÔNIOS}

Segundo a doutrina teológica cristã, Satanás é um anjo e, portanto, um ser puramente espiritual. Foi criado por Deus e possuía um enorme esplendor, ocupando uma alta 
posição na hierarquia angélica. Essa posição é afirmada por São Tomás de Aquino e retomada por Gabriele Amorth.

Satanás é um anjo criado bom, mas que se rebelou contra Deus e afastou-se Dele (...) Em certo sentido, o demônio tornou-se um Antideus, aquele que combate os planos do Senhor, porque se rebelou por primeiro, repudiou a obediência e o desígnio que Deus tinha sobre ele. Como foi dito, Satanás é um anjo decaído e, portanto, como os anjos, é puro espírito. Assim sendo, não possuindo corpo, se quiserem apresentar-se, precisam assumir uma forma visível e sensível, adequada à percepção do homem (...). (AMORTH, 2013. p.16-17).

Os ensinamentos do padre Gabriele Amorth estão em conformidade com as determinações do IV Concílio de Latrão e com o atual Catecismo da Igreja Católica, cujo conteúdo estabelece " Como criaturas puramente espirituais, são dotados de inteligência e de vontade: são criaturas pessoais e imortais. Superam em perfeição todas as criaturas visíveis." (330)[4]. Segundo São Tomás, esses seres espirituais não são limitados pelo tempo nem pelo espaço, mas suas ações se restringem a um lugar ou pessoa. Assim "é pela aplicação do poder angélico a um lugar, de certa maneira, que se diz que o anjo está em um lugar corpóreo"(cf. q. 52, a. 1) (TOMAS DE AQUINO, 2005, p. 263).

São Tomás ressalta que Deus criou os anjos, mas estes não $O$ contemplavam diretamente. Posteriormente, Deus se revelou de forma indireta e lhes deu uma escolha de amor e união perfeita. Alguns, optaram pela união amorosa com o Criador e acabaram sendo admitidos à presença do Santíssimo onipotente. A partir de então, passaram a contemplar a visão beatífica e santificante de Deus e perderam sua liberdade, uma vez que foram irrevogavelmente atraídos para Ele, o Sumo Bem, Criador de todas as coisas.

Embora não seja possível um conhecimento pleno acerca do que se constituiu a prova dos anjos, é certo que alguns deles recusaram a obediência a Deus, transgredindo suas ordens e consumando pecados essencialmente espirituais, ou seja, entregaramse aos pecados da soberba e da inveja. A soberba é o principal pecado, cuja essência consiste em querer ser igual a Deus, não por natureza, mas por semelhança, ou seja, Satanás desejou ser Deus a partir de sua própria natureza, sem o apoio e 
dependência do dom da graça sobrenatural, almejando a autossatisfação e voltando as costas para o verdadeiro Sumo Bem, Deus.

São Tomás frisa que o número dos anjos que decaíram foi menor do que aqueles que permaneceram fiéis ao Criador. Portanto, a realidade angelical beatífica é muito maior que a diabólica. Por este motivo, a esperança cristã não deve demonstrar terror e pavor diante do maligno. A teologia tomista também ressalta a existência de uma hierarquia de importância entre os demônios. Sobre este assunto, o padre Amorth (2013, p.21-22) afirma que os demônios são verdadeiros servos do Maligno: anjos que o seguiram em sua queda do paraíso e se sujeitavam aos seus desígnios. Sendo assim, é possível vislumbrar uma certa hierarquia entre eles, contudo essa estrutura hierárquica é fundamentada no medo e na opressão, e não pelo amor, como se verifica nos anjos que permaneceram no paraíso.

Na questão de número 64, artigo 1 da Suma Teológica, São Tomás discorre sobre o intelecto de Satanás. O autor irá afirmar que a inteligência do maligno se encontra obscurecida, sendo capaz de conhecer as coisas de forma natural, já que o conhecimento das verdades reveladas foi negado ao demônio. Ademais, a legião diabólica está privada da graça eficaz e santificante de Deus. " [satanás] não vê Deus face a face e, portanto, o acesso que possui restringe-se tão somente àquilo que the fora revelado antes do pecado ou àquilo que ele recebeu dos anjos (...)"[5].

Vale ressaltar que, segundo a espiritualidade cristã, Satanás é inteligente, mas não sábio, uma vez que não está obcecado intelectualmente no sentido pleno da palavra, ou seja, não assume um compromisso com a contemplação da Verdade, mas tão somente com a degradação do testemunho cristão. Não obstante a misericórdia plena do Santíssimo Criador, a vontade de Satanás é obstinada no mal, e, portanto, não há arrependimento para ele. Para São Tomás, a perspectiva de Orígenes sobre a restauração universal é completamente equivocada e distante das doutrinas elementares do Evangelho. "à misericórdia de Deus liberta do pecado os penitentes. Mas aos incapazes de fazer penitência, que aderem ao mal de maneira imutável, a misericórdia divina não os liberta." (TOMÁS DE AQUINO, 2005, p.262) 
O artigo 3 da questão de número 64 da Suma Teológica comenta sobre a dor existente nos demônios. Basicamente, o demônio sofre quando tem sua vontade contrariada. Sobre o assunto, Aquino comenta:

Enquanto paixões, o temor, a alegria, a dor e atos semelhantes não podem existir nos demônios, pois são próprios do apetite sensitivo, que é uma faculdade que supõe um órgão corporal (...) Sabe-se que os demônios quereriam que muitas coisas que existem não existissem, e que existissem muitas coisas que não existem, pois, invejosos, quereriam a condenação dos que foram salvos. Daí se deve dizer que eles têm dor, até porque é da razão da pena ser contrária à vontade. Ademais, se os demônios estão privados da felicidade natural que podem desejar, e em muitos deles, encontra-se inibida sua vontade pecadora. (TOMÁS DE AQUINO, 2005, p.263)

A invocação do Santo nome do Senhor Jesus Cristo, o sangue libertador de Cristo e o nome da Virgem Santíssima são ideias insuportáveis ao demônio, conforme apontam São Tomás, Padre Amorth e o Venerável Fulton Sheen.

As observações apontadas neste capítulo correspondem a uma descrição teórica dos aspectos gerais da natureza demoníaca, principalmente conforme os escritos de São Tomás de Aquino e do padre Gabriele Amorth. Os próximos temas irão tratar propriamente sobre a ação dos demônios sobre os homens.

\section{A NATUREZA DA AÇÃO DEMONÍACA}

A ação demoníaca, segundo o entendimento comum da teologia sistemática, é classificada em ação ordinária e extraordinária. Contudo, antes de discorrer propriamente sobre este tema, uma melhor explicação e compreensão acerca das questões preliminares sobre a ação do demônio se faz necessária, tais como: "Qual é a natureza da ação de Satanás e de seus servos?", "Por que a ação do demônio é tão forte contra os homens?" e "O que dever ser feito para estar pronto espiritualmente para combater o demônio a cada dia?".

O padre Gabriele Amorth era categórico na afirmação de que antes de compreender a ação de Satanás é necessário ter em mente que o demônio apresenta uma força imensa. A imensidão desse poder é atestada até mesmo nas Sagradas Escrituras, 
quando Cristo o chama de "príncipe deste mundo" e São Paulo de "o deus deste mundo". São João diz: "todo o mundo jaz sob o poder do maligno".

Sendo assim, todos sofrem com as ações diabólicas. Nem mesmo Jesus Cristo foi imune a ação de Satanás. Contudo, o ser humano apresenta liberdade para resistir às insídias demoníacas e Deus, em Sua misericordiosa providência, não permite nunca que sejamos acometidos por tentações superiores às nossas forças.

O homem possui o senso do bem e do mal, e tem a força para resistir às seduções de Satanás, que, sempre usa um método muito sorrateiro; como diz São Pedro, de fato, anda ao redor de todas as criaturas tentando devorá-las, buscando seu ponto fraco que, em geral, encontram-se num dos três vícios fundamentais: a soberba, que é o desejo de ganhar, de nos tornarmos grandes e poderosos; a riqueza, a sede de dinheiro, pois com o dinheiro se pode chegar a todos os lugares; o vício, nas suas múltiplas formas, já que o ser humano tem a tendência de buscar o prazer, sobretudo os proibidos, que são contra o Pai. (AMORTH, 2018, p. 15)

Além dos remédios espirituais para o combate ao Maligno que serão mencionados posteriormente, o homem tem um suporte fundamentado na Revelação Geral de Deus, ou seja, os seres humanos apresentam o discernimento do bem e do mal impressos em seus corações. São Tomás utiliza o termo "lei natural" para se designar a essa impressão. Para o Doutor da Igreja, a lei natural seria a "participação da lei eterna na criatura racional", cujo conteúdo permite ao homem discernir o bem natural daquilo que é explicitamente reprovável no âmbito moral.

A ação de Satanás é tão forte contra o homem pois está fundamenta na soberba do demônio amalgamada com o poder e grandeza conservados pelos anjos caídos. Satanás tornou-se o ser criado que mais manifesta e alimenta um ódio nefasto em relação a Deus; "ele põe toda a sua inteligência, as suas forças e o seu poder nesta raiva contar o Senhor e tenta o homem para empurrá-lo a fazer o mal. Quer arrancarnos do Pai (....)" (AMORTH, 2018, p.16).

O objetivo do demônio é fazer com que o homem se afaste de seu propósito maior e vocação primordial: a união afetiva com Deus. Sendo assim, tamanha importância da demonologia que em um discurso de Paulo VI, em 1972, na ocasião da Audiência de 
quarta- feira, quando os papas procuram transmitir seus ensinamentos aos fiéis, começou seu grande discurso deste modo: "Não vos maravilheis se vos digo que uma das maiores necessidades da Igreja é alertar contra aquele terrível perigo representado por Satanás". Contudo, ainda assim, muitos teólogos procuram atenuar e até mesmo desconsiderar a ação demoníaca sobre os homens. Certamente, os perigos da modernidade favorecem as obras de Satanás e a expansão de seu reinado da apostasia. O padre Amorth explica que a cosmovisão pós-moderna facilita a ação diabólica em sua tarefa de fomentar a mentira e abalar as verdades primordiais e basilares do Evangelho. O ocultismo, o materialismo, naturalismo, niilismo e idolatria são posturas estruturais do pós-modernismo que, em última instância, afastam o homem de Deus e banalizam a existência do demônio e de suas atividades.

$\mathrm{Na}$ atualidade, chegamos ao paradoxo de gente que não crê, ou que afirma não crer em Deus, mas corre atrás das referências astrais ou de ilusões inúteis e igualmente buscam combater as influências malignas. O percentual das pessoas que dependem da irracionalidade é crescente e poder-se-ia dizer paralisante. A Providência não, o horóscopo sim; a Igreja não, a bruxa sim. A primeira vitória de Satanás é convencer com pretextos talvez pseudoculturais que ele não existe ou, no máximo, é apenas um boneco agitado para causar medo em crianças más; mas por outro lado, seria cômodo demais descarregar todo mal sobre o Diabo, como para nos apresentarmos, quase sem qualquer esforço, com uma consciência assaz limpíssima. (MAZZALI, 2017, p.21)

Padre Amorth irá afirmar que a incredulidade é fonte de superstições e idolatria. Daí o motivo do paradoxo apresentado pela citação supramencionada. Por mais que o mundo moderno afirme seu comprometimento com os preceitos do cientificismo e da racionalidade pura, a superstição cresce cada vez mais. Santo Agostinho já apontava que o "vazio existencial infinito" do coração humano não pode ser preenchido com coisas e prazeres finitos, mas somente com a união amorosa com Cristo, cuja infinitude de misericórdia e bondade sustenta toda a realidade criada. Se não estivermos em uma relação de intimidade com Deus, a idolatria ocupa o centro do coração e da vontade, sujeitando o homem a uma "falsa noção de felicidade". Eis o grande trunfo do demônio, uma vez que da idolatria, as práticas de ocultismo e superstição ganham forças. "Eis que quando não se crê mais no Onipotente, se cai na superstição, na idolatria" (AMORTH, 2018, p.35). 
Conforme já destacado, vale frisar que uma outra postura equivocada do pósmodernismo consiste em subestimar ou negar a presença da ação de Satanás na história geral e pessoal dos homens. Essa mentalidade é fruto do materialismo e de uma cosmovisão pautada no relativismo moral. "Não podemos negar a realidade do Inferno e do demônio. Aqueles que não creem na existência do maligno caem nas armadilhas preparadas por ele' (AMORTH, 2018, p.46).

Depois de discorrer de forma genérica sobre a natureza da ação demoníaca, o padre Amorth explica brevemente acerca dos métodos e meios para vencer a batalha espiritual. Basicamente, três são os métodos principais: oração, instrução, sacramentos. "Eis a força que nos faz vencer Satanás e as tentações que vêm do mundo: a fidelidade à oração, aos sacramentos, à educação cristã (...)" (AMORTH, 2018, p.31). Outro aspecto necessário a ser levado em consideração na defesa contra o demônio consiste na intercessão e três são os intercessores maiores: o Espírito Santo, o nome de Jesus e Maria Santíssima. Na concepção dogmática, a importância de Maria na luta contra o demônio decorre não somente do fato de ser Mãe do Redentor, mas também colaboradora em Sua obra Redentora, sendo representada popularmente no ato de esmagar a cabeça da serpente.

A invocação de São Miguel Arcanjo, São Bento, Santo Antão, Santa Maria de Jesus Crucificado, Santa Catarina de Sena e Santa Gemma Galgani também se demonstra extremamente útil. Todos esses santos enfrentaram o demônio. São Bento era um monge que demonstrou grande força contra o Demônio. Santo Antão, o Eremita, era um dos grandes Padres do Deserto e sofreu fortes pressões das obsessões diabólicas.

Deve-se ter em mente, contudo, que o medo maior não deve ser em relação ao demônio. Nesse ponto, a ideia central da obra "O hobbit" de J.R.R Tolkien resume, de forma sintética e esclarecedora, o que de fato é necessário para lutar contra o maligno. $\mathrm{Na}$ adaptação cinematográfica do livro, a personagem Galadriel pergunta ao mago Gandalf o motivo pelo qual ele escolheu um indivíduo tão simples e comum para uma aventura decisiva contra o reinado e opressão das forças malignas. Ele responde: "Saruman acredita que apenas um grande poder pode manter o mal sobre controle, 
mas não é o que descobri. Descobri que são as pequenas coisas, as tarefas diárias de pessoas comuns que mantém o mal afastado, simples ações de bondade e amor". Continuando essa linha de pensamento, é importante traçar um paralelo com os pensamentos de Santa Teresa de Lisieux: "Não perca sequer uma oportunidade de fazer um pequeno sacrifício. Um sorriso aqui; uma palavra gentil acolá. Sempre fazendo pequenos atos de bondade; e sempre fazendo tudo por amor".

Compreendo, agora, que a caridade perfeita consiste em suportar as faltas dos outros, em não se admirar com as suas fraquezas, em edificarse com os menores atos de virtude que eles praticam, mas, sobretudo, compreendi que a caridade não deve ficar fechada no fundo do coração. Ninguém, disse Jesus, acende uma lâmpada para pô-lo debaixo da mesa, mas sobre o candelabro, a fim de que ilumine a todos os que estão em casa. Parece-me que essa lâmpada representa a caridade que deve iluminar, alegrar, não apenas os que me são mais caros, mas todos aqueles que estão em casa.[6]

A vitória contra o demônio consiste na caridade, no amor fraterno. Realizar pequenos atos de virtude tendo em vista o Sumo Bem é a verdadeira piedade prática. Humildade amalgamada com a magnanimidade é o caminho para a santidade. Portanto, quem pensa que a batalha espiritual só é vencida com poder, orgulho ou até mesmo com grandes feitos, segue uma linha equivocada sobre o que seria a autêntica vida espiritual e vitória sobre Satanás. Exemplo da caridade e de humildade nessa luta constante é São Miguel arcanjo.

De fato, é doutrina comumente aceita que os anjos estão distribuídos em três hierarquias: suprema, média e ínfima, cada uma das quais se divide em três ordens, totalizando assim nove coros angélicos, cujos nomes são claramente mencionados na Escritura. São eles, em ordem descendente: serafins, querubins e tronos; dominações, virtudes e potestades, principados, arcanjos e anjos. Na hierarquia celeste, por conseguinte, São Miguel pertence ao coro dos arcanjos, a segunda classe da ordem mais inferior, por ser a mais distante de Deus e, ao mesmo tempo, a mais próxima dos homens (...).[7]

São Miguel Arcanjo, mesmo pertencendo a uma das ordens mais baixas na hierarquia angelical, conseguiu derrotar Satanás e seus demônios, conforme informado na tradição bíblica. "Deus resiste aos soberbos, mas dá sua graça aos humildes" $(\operatorname{Pr} 3$, 34; cf. $\operatorname{Tg} 4,6)$. A principal grandeza de São Miguel reside, pois, em sua pequenez, 
em sua humildade, em sua submissão a vontade de Deus, em sua obediência. Sendo assim, devemos imitar essas características para que não sejamos enganados pelas insídias do demônio, da carne e do mundo.

Enfim, após uma breve exposição introdutória sobre a natureza da ação demoníaca, se faz necessário abordar de forma mais aprofundada os tipos e categorias dessa ação bem como as peculiaridades de cada uma delas. Basicamente, as ações do demônio são: tentação, vexação, infestação, obsessão e possessão.

\subsection{A TENTAÇÃO}

A tentação é a ação ordinária do demônio. Apesar de popularmente a possessão ser considerada uma das atividades demoníacas mais nefastas, a tentação é a mais perigosa e mais importante e, por este motivo, precisa de maior explicação. São Tomás de Aquino na I seção, questão 114, artigo 2 da Suma Teológica afirma que Satanás "sempre tenta para prejudicar, impelindo ao pecado." Portanto, é próprio do Diabo tentar o homem, é o seu ofício.

O combate contra tentação é cotidiano, diário. São Tomás procura frisar essa importante lição, citando dois versículos da Carta de São Paulo aos Efésios:

Revesti-vos da armadura de Deus para que possais resistir às insídias do diabo. A nossa luta não é contra a carne e o sangue, mas contra os Principados, as Potestades, contra os dominadores desse mundo tenebroso, contra os espíritos malignos espalhados nos ares. $(6,11-12)$.

Vale ressaltar que nem todas as tentações provém do demônio. A teologia espiritual católica enumera outros dois inimigos do cristão, além do demônio, são eles: o mundo e a carne. O Concílio de Trento já frisava essa verdade ao afirmar "sabendo que foram regenerados na esperança da glória, devem temer pela batalha que ainda resta contra a carne, contra o mundo, contra o diabo, da qual não podem sair vencedores, se não obedecerem, com a graça de Deus, às palavras do Apóstolo." (DH 1541).

Na teologia bíblica, a carne, primeiro inimigo do homem, refere-se a desordem interna existente em cada ser humano devido ao pecado original. É a tendência a depravação 
e a transgressão da Lei de Deus. Tem origem com o pecado original e ganha forças com os pecados pessoais do cotidiano. Sobre o assunto, São Tomás (AQUINO, 2002, p.263) comenta que o diabo não é a causa imediata de todo o pecado, já que algumas transgressões são cometidas pela liberdade do arbítrio do homem e pela corrupção da carne.

O segundo inimigo do cristão é o mundo, compreendido enquanto a cosmovisão de rejeição aos dogmas elementares da fé, cujo intuito é fazer o homem se distanciar de Deus. Materialismo, naturalismo, niilismo, hedonismo e individualismo são algumas das mentalidades centrais que formam a cosmovisão do "mundo" no sentido bíblico. O terceiro inimigo, por fim, é o demônio.

Importante frisar que a tentação que provém do demônio apresenta uma psicologia, uma forma de acontecer com etapas e progressões. Se a pessoa não apresenta a lei natural bem desenvolvida e não conta com o auxílio da graça divina, ela cai muito facilmente nas insídias do maligno e, muitas vezes, as etapas da tentação não ocorrem, pois o maligno não precisa de muitos esforços e investidas para induzi-la ao erro. Para os indivíduos virtuosos, o Diabo segue todo um "procedimento" cauteloso e meticuloso.

Segundo o padre Antônio Royo Marín, a primeira etapa é a aproximação do diabo. A segunda é o ataque do demônio. Importante dizer que Satanás é ótimo observador e se vale das informações adquiridas por meio da observação para consumar uma tentação. Embora não tenha acesso direto aos pensamentos dos homens, os seres diabólicos analisam a vida e as atitudes cotidianas das pessoas, para depois atacálas em seus pontos fracos. Tendo posse de informações acerca da vida do indivíduo, o demônio lança uma insinuação para que a pessoa comece o diálogo em sua mente acerca da ideia que the fora apresentada.

A terceira etapa corresponde a resposta da pessoa à sugestão recebida. O Diabo quer estabelecer uma conversa com a pessoa e almeja fazer com que ela demonstre sinas de dúvidas acerca de suas convicções morais. A quarta fase, a proposta do pecado, sempre vem seguida de uma mentira, uma falácia relacionada a vida espiritual, ao 
caráter de Deus e a felicidade que provém da vida virtuosa, ou seja, o demônio apresenta uma falsa proposta de felicidade.

A quinta etapa, a vacilação, é um pecado venial, pois a pessoa já se vê cometendo o pecado e contempla essa hipótese, degustando-a mentalmente. Em seguida vem o consentimento, ou seja, a consumação do ato pecaminoso. Por fim, a etapa do arrependimento, que não é de todo mal, revela ao homem pecaminoso que este rompeu com sua vocação para santidade e para união afetiva com Deus; reforçando a necessidade imediata de contrição e perdão.

O padre Gabriele Amorth frisa todos os todos os aspectos supramencionados. Segundo ele, a tentação é o método mais utilizado por Satanás para desviar o homem de sua nobre vocação.

O que mais interessa ao demônio é, sem dúvida, fazer o homem cair no pecado, e distanciá-lo de Deus; quer que, ao invés de ir ao Paraíso, desça com ele ao Inferno. É isso que o impulsiona, em primeiro lugar. As outras coisas, para ele, são secundárias; porém, como dissemos antes, tenta, levando em conta os pontos fracos de cada um, atacando precisamente ali, nos pontos fracos. Começa com as coisas pequenas, faz o mal parecer um bem, como um ganho, como um modo de adquiri conhecimentos que antes não tínhamos (...) acontece frequentemente. As pessoas se sentem convidadas a fazer o mal como se fosse um bem; talvez se trate de uma ação muito comum a que, pouco a pouco, se cede e que depois se torna um vício, um hábito. Então se buscam mil justificativas, mas não se pensa mais no essencial, isto é, que aquela coisa é contrária à lei do Senhor. Perde-se completamente o senso de Deus e não se crê mais n’Ele. (AMORTH, 2018, p. 54-55)

Padre Amorth também ressalta que resistir às tentações é uma grande conquista no caminho para santidade e que, em meio ao árduo contexto das provações, nunca devemos perder a confiança na misericórdia de Deus. Conforme ressalta o Catecismo da Igreja Católica, o poder de Satanás não é infinito, já que ele não passa de criatura. Sendo assim, embora sua atuação no mundo seja forte e pautada num ódio imenso contra Deus, Satanás não é capaz de impedir a edificação do Reino de Deus. Outro ponto importante reside no fato de que a permissão divina da atividade diabólica é um mistério, mas nunca o fiel deve perder a esperança, já que tudo contribui para o bem daqueles que amam Deus[8]. 
Nesse sentido, São Tomás de Aquino escreve: "É para tornar maiores os nossos méritos, mais puras e mais elevadas as nossas virtudes, mais rápido o nosso caminho para ele, que Deus permite ao diabo tentar-nos e colocar-nos à prova" (BAMONTE, 2007, p. 35) (cf. Commento alla lettera agli abrei). São João Crisóstomo resume de forma sintética, certeira e esclarecedora sobre o assunto:

Se vos perguntarem por que Deus tenha deixado subsistir o Demônio depois de sua rebelião, respondei: Deus deixou-o subsistir para que, longe de fazer o mal aos homens atentos e vigilantes, o Demônio se torne útil para eles. Não certamente pelo fato da sua vontade, que é perversa, mas graças à corajosa resistência daqueles que fazem transformar-se a malícia dele para vantagem sua. (BAMONTE, 2007, p.35)

Padre Fortea (2010, p.45) ressalta a importância da vontade no duro combate às tentações. A determinação da vontade e seu direcionamento em relação ao Sumo Bem amalgamadas com o auxílio da graça divina representam o segredo para vitória sobre o maligno. O demônio pode até tentar introduzir pensamentos nefastos, imagens ou recordações, porém não pode introduzir-se no âmago da vontade humana. Portanto, embora a tentação de origem demoníaca possa afligir os homens, ela não é capaz de forçar alguém a cometer nem mesmo o menor dos pecados veniais.

O teólogo Joel Beeke enumera várias artimanhas de Satanás para destruir a fé, fidelidade e testemunho dos cristãos. As principais são:

Satanás é mestre em sugerir que acreditemos naquilo que queremos crer, em vez de crer na verdade (...) Satanás oferece a isca do prazer que esconde o anzol do pecado (...) Satanás apresenta o pecado como se fosse uma virtude. Ele minimiza o pecado para manter preso o pecador. Orgulho torna-se autoestima, cobiça se torna ambição, e bebedeira se torna comunhão (...) Satanás nos estimula a fazer amizades com pessoas mundanas. Sabe que a associação gera assimilação e assim nos seduz ao pecado por meio de amizade com pessoas ímpias (...) Satanás apresenta gente não convertida como pessoas que possuem muitas vantagens externas e poucas tristezas, e os crentes como possuidores de poucas misericórdias externas e muitas tristezas. Deste modo, Satanás tenta nos convencer que servir a Deus é em vão (...) Satanás minimiza a seriedade do pecado, e então nos leva a pecados ainda maiores. O pecado nos assola, passando dos 
pensamentos para os olhares (...) Satanás nos faz enfocar o quanto é difícil praticar as disciplinas espirituais (...) Satanás aflige nossa mente com pensamentos vãos para nos distrair de buscar a Deus mediante as disciplinas espirituais (....) (BEEKE, 2018, p.103-112).

O importante a se destacar é que o combate se dá no campo das ideias, uma vez que os anjos maus atuam tendo em vista inclinar a vontade humana para o pecado, já que não são capazes de coagir a vontade dos homens. O padre Amorth é categórico em afirmar que uma das maiores tentações consiste em impulsionar o coração humano a nutrir uma desconfiança em relação a misericórdia de Deus. Devemos ter em mente que Deus está disposto a perdoar os pecados, desde que busquemos verdadeiramente o arrependimento e a contrição.

O combate às tentações consiste em três fases: antes, durante e depois. Na primeira fase, o remédio é simples "Vigilância e oração". Nosso Senhor Jesus Cristo ensinou: "Vigiai e orai para que não entreis em tentação." (Mt 26, 41). A vigilância é uma atitude de atenção constante em relação à vitória alcançada na Cruz pelo Cordeiro Imolado para os seus filhos eleitos. O sangue de Cristo possui um efeito de libertação das amarras e da escravidão do pecado. Entretanto, Satanás faz de tudo para que as almas percam a perseverança e se afastem do que foi conquistado na Cruz por Cristo.

Vigilância é estar sempre atento às ocasiões de pecado, alertando nossa consciência dos momentos mais oportunos para os ataques demoníacos. Sobre este assunto, o padre Amorth (2018, p. 59) comenta que é necessária muita cautela e prudência, especialmente nas escolhas diárias concernentes aos hábitos de companhia, espetáculos que assistimos, do uso que se faz da televisão e da internet, dentre outros.

O combate à ociosidade é uma das grandes manifestações de uma postura vigilante. Outro ponto necessário é a oração, pois se trata de uma postura de quem nutre verdadeiramente um amor fraterno. O pecado prejudica o homem em sua vida física e espiritual, nutrindo no coração humano um amor desordenado de si mesmo, ou seja, acaba por promover o puro egoísmo. A oração, por outro lado, é uma forma de reconhecer a dependência de Deus e de suas bençãos, reconhecendo as debilidades 
pessoais e a necessidade de uma sujeição à perfeição, glória e Santidade de Cristo. Por este motivo, a oração se faz necessária, pois ninguém consegue vencer plenamente as tentações sem o auxílio da graça eficaz divina.

Padre Amorth frisa que Deus concedeu dois grandes auxílios na batalha contra as insídias demoníacas e o pecado: a Virgem Maria e o Anjo da Guarda. A Virgem Maria, símbolo de grande humildade, é completamente oposta aos pecados de orgulho e soberba tão marcantes nos demônios. Já, os Anjos da Guarda movem e inclinam a vontade humana a realmente querer Deus, potencializando nosso próprio entendimento; excitando frequentemente em nossas almas pensamentos santos e aumentando as graças atuais.

(...) Mesmo se ninguém nos ajuda, Nosso Senhor e Nossa Senhora nos seguem e estão próximos e é para eles que devemos nos voltar. Ninguém está sozinho, porque todos temos a Deus. (...) Então, devemos rezar. Assim sentiremos o Criador que fala conosco (...) devemos nos voltar ao Senhor, que não nos deixa nunca. Ele está sempre presente e acompanhado de Maria, do nosso Anjo da Guarda e dos santos, sobretudo de nosso onomástico. (AMORTH, 2018, p.57-58)

Durante a tentação, existem duas formas de resistência: a direta e a indireta. A resistência direta nada mais é do que agir contra, ou seja, ao perceber que está sendo tentado a agir de uma determinada maneira, volta-se para a direção oposta. Sendo assim, se uma pessoa está sendo tentada pela avareza, ela deve dar uma esmola e se afeiçoar rapidamente a virtude da liberalidade. No entanto, a luxúria e a incredulidade são pecados, cujas tentações não devem ser resistidas diretamente, mas de forma indireta. Os Santos Padres explicam que no combate contra a luxúria, os demônios apresentam um forte aliado: o corpo, que apresenta uma tendência a concupiscência. Portanto, a melhor forma de lutar nesse caso é simplesmente fugindo das seduções carnais.

A tentação demoníaca da luxúria ocorre quando a pessoa é assaltada, de forma repentina, por pensamentos sexuais e carnais. De modo concreto, o ideal é sempre usar das próprias faculdades da memória e da imaginação para fugir dos pensamentos luxuriosos, levando o pensamento para aspectos práticos, cotidianos e 
de trabalho. A ansiedade gerada pela tentação pode levar ao desânimo, ao desespero e à desistência de perseguir a santidade. Entretanto, nunca devemos nos entregar a ansiedade, mas tão somente ao descanso nas mãos da Providência Divina.

A tentação vencida, conforme ressalta São Tomás de Aquino, é ocasião de mérito diante de Deus, pois representa uma verdadeira prova de amor. A terceira etapa da tentação apresenta três possibilidades: a pessoa venceu a tentação, caiu nela ou ficou em dúvida se caiu ou não. Se venceu, deve sempre agradecer a Deus e nunca cair no pecado da vanglória, gabando-se que saiu vitorioso unicamente pelas próprias forças. Quando a pessoa caiu na tentação, deve fazer do pecado uma verdadeira lição de santidade, humilhar-se e envergonhar-se pela falta praticada. Se o pecado foi mortal, deve rapidamente realizar uma confissão e arrependimento eficaz. Se a falta representa um pecado venial, a pessoa pode fazer um ato de contrição perfeito, nutrindo resoluções efetivas de não mais transgredir a lei de Deus.

Se ficou em dúvida se caiu na tentação, o importante é realizar uma meditação e um exame de consciência, sendo melhor esperar até se recuperar do ataque para avaliar categoricamente se a falta realmente ocorreu.

Conforme já ressaltado, nem todas as tentações provêm do diabo. Algumas são oriundas da carne e do mundo, entretanto, se soubermos como vencer as mais variadas tentações, certamente sairemos vitoriosos nas mais diversas batalhas espirituais, porquanto tudo aquilo que nos defende do pecado, nos protege do inimigo invisível. Sendo assim, se faz importante mencionar dicas práticas para vencer as tentações provenientes da carne e do mundo. São elas:

- Mortificar-se nas coisas lícitas;

- Afeiçoar-se à Cruz e ao sofrimento;

- Combater fervorosamente a ociosidade;

- Fugir das ocasiões de pecado;

- Meditar a respeito da dignidade do cristão e da vocação para santidade;

- Lembrar-se do Inferno e da possibilidade do castigo eterno;

- Recordar-se continuamente sobre a Paixão de Cristo; 
- Orar com perseverança e verdadeira humildade;

- Frequência nos Sacramentos;

- Verdadeira Devoção a Virgem Santíssima.

Apesar da variedade das tentações e insídias demoníacas e da carne, as mais perigosas consistem em fazer com que Deus se torne secundário e supérfluo na vida do homem. Sobre o assunto, Joseph Ratzinger (2007, p. 41-42) comenta que aspecto central de toda tentação consiste na tentativa e nas investidas de colocar Deus de lado, ou seja, de promover uma marginalização das práticas espirituais. O desejo constante de construir o mundo autônomo sem Deus é a maior tentação e, por conseguinte, uma das mais graves.

Além do desprezo para com o mundo espiritual, outra grande tentação consiste no não reconhecimento das próprias faltas. O não reconhecimento do próprio pecado impede o sentimento de culpa do qual procede o real arrependimento. Venerável Fulton Sheen estabelece que essa falta de conhecimento acerca de si mesmo e de suas limitações é um motivo de grande satisfação para o demônio. Portanto, grande atenção é necessária para os aspectos supramencionados.

Para finalizar as ponderações acerca da tentação, vale ressaltar as frases de Winston Churchill em seus renomados discursos, que embora não se refiram diretamente a batalha espiritual, contêm preciosas lições para Escola de Santidade: "A lição é a seguinte: nunca desista, nunca, nunca, nunca. Em nada. Grande ou pequeno, importante ou não. Nunca desista. Nunca se renda à força, nunca se renda ao poder aparentemente esmagador do inimigo"/ "Todas as grandes coisas são simples. E muitas podem ser expressas numa só palavra: liberdade; justiça; honra; dever; piedade; esperança." Conforme ressalta Venerável Fulton Sheen, são as pequenas lutas diárias que revelam o caráter moral da pessoa, sua disposição em praticar de forma constante as virtudes bem como a intensidade de sua caridade. Portanto, as pequenas batalhas do dia a dia são as mais importantes e nunca devem ser subestimadas na luta contra as tentações. 


\subsection{INFESTAÇÃO E VEXAÇÃO}

A infestação ou assolamento é uma ação extraordinária do demônio que consiste basicamente na utilização da natureza inanimada ou animal para assolar e oprimir o homem, sujeitando-o ao medo, instabilidade emocional e até mesmo desespero. Segundo o padre José António Sayés, " a infestação diabólica é uma moléstia que o Diabo desenvolve na natureza inanimada (ou animal) para prejudicar com ele o homem"(SAYÉS, 1999, p.153). Sobre o assunto, Padre Amorth escreve:

O assolamento, ao invés, é outro termo que utilizo, reservando-o exclusivamente às casas, aos objetos e aos animais. Temos exemplos desde os tempos da patrística, com Orígenes, de exorcismos efetuados não apenas para libertar o homem, mas também lugares, objetos e animais. O Evangelho nos apresenta o exemplo daquele possesso de Gerasa; por meio de sua boca, o diabo pede ao Senhor para transferirse para uma manada de porcos e entra efetivamente nestes animais, que certamente, naquele momento, ficam endemoniados. (AMORTH, 2013, p.29)

A infestação pode ser de dois tipos: local- quando a ação diabólica afeta lugares ou casas- e pessoal- quando os demônios procuram exercer sistematicamente uma moléstia, mal físico e até mesmo psíquico ao homem. O padre Amorth é categórico em dizer que a maioria dos casos por ele atendidos não são de possessão, mas de infestação pessoal. Vários são os sinais de infestação, tais como:

(...) rumores ou pancadas no teto ou em casa sobre o pavimento ou nas paredes, nas portas, ou nas janelas ou nos móveis, saraivada de pedras, que caem como do nada sobre o teto ou também na casa; rumores de passos invisíveis; sons como tiros ou explosões ou ribombos; grande rumor de correntes e de ferragem; vozes misteriosas ou então urros, risadas, barulhos; sons e cantos muitíssimos estranhos, de dia e/ou de noite; desaparecimento de objetos que, ou não são mais reencontrados, ou então são encontrados nos pontos mais impensáveis da casa; improvisos e intensíssimos odores de queimado ou de esterco, ou de enxofre, ou de carniça, ou de incenso; sopros imprevistos em ambientes totalmente isentos de correnteza de ar; portas e janelas que se abrem e fecham simultaneamente, vidros de janelas que se quebram também todas ao mesmo tempo; (...) gastos inexplicáveis nos eletrodomésticos, acendimento e apagamento de lâmpadas sem ter tocado nos interruptores (...) aparições várias de sombras ou de pessoas ou de seres deformados (...) outros objetos da casa são arremessados com 
violência pela sala, como sinal concreto de ameaça para os moradores. (BAMONTE, 2007, p.72-74)

Padre Amorth ressalta que é muito trabalhoso resolver casos de infestação, pois exige grandes esforços. Abençoar todos os locais do imóvel com água benta e incenso, orações de libertação e exorcismo bem como a utilização dos sacramentais (bênção do óleo, sal e água benta) são grandes instrumentos para o combate das infestações.

(...) devo dizer que para libertar uma casa infestada pelo demônio é preciso tempo e trabalho; é preciso ir muitas vezes, repetir o ritual e abençoar todos os locais com água benta e incenso- também este último é muito eficaz. Com esses elementos e com oração do exorcismo adaptada para a casa, diferente daquela reservada às pessoas, é possível obter bons resultados (...) Depois segue assim: "Senhor, pedimos tua clemência para abençoar e santificar; que todos aqueles que o bebem tenham a saúde da mente e do corpo, e qualquer influência maléfica que esteja sobre eles, seja expulsa." (AMORTH, 2018, p.82-84)

Sobre o assunto, padre Fortea (2010, p. 2019) comenta sobre obrigação que o sacerdote possui de incentivar a família a orar constantemente, rezar o rosário, ler a Bíblia unidos e reunir-se ante a uma imagem sagrada e realizar súplicas de proteção e orações de libertação.

A infestação acontece muitas vezes a partir de objetos que, de certo modo, podem provocar "mal-estar". Na maioria das vezes, objetos não sagrados, funestos e até mesmo "ídolos" são passíveis de maiores malefícios. O ideal é sempre se livrar o mais rápido possível desses objetos suspeitos.

Padre Amorth frisa que as infestações são fenômenos raros e, por este motivo, os exorcistas necessitam do apoio de psiquiatras para averiguar se a pessoa que sofre com a suposta "infestação" é afetada por distúrbios patológicos ou males psicológicos.

A vexação é uma das outras ações extraordinárias do demônio e consiste em agressões físicas a uma pessoa por iniciativa dos anjos demoníacos, como cortes, queimaduras, arranhões, mordidas, golpes que deixam grandes marcas, inchaços e, no pior das hipóteses, fraturas. "Podem ser consideradas vexações também aquelas perseguições encarniçadas, insistentes e inexplicáveis sob o perfil humano, que os 
demônios suscitam contra uma pessoa correta por conta de outras" (BAMONTE, 2007, p.80).

A vexação também atinge os afetos da pessoa através de constantes humilhações, conforme ressalta o padre Amorth. Um personagem bíblico marcante que sofreu com a ação extraordinária em questão foi Jó. Sobre isso, Amorth discorre:

Já é ferido em seus afetos: recebe a notícia da repentina morte de todos os seus dez filhos; é ferido em seus bens: de riquíssimo, subitamente torna-se paupérrimo; é ferido na saúde: era sadio e fica coberto com chagas, da cabeça aos pés; entretanto, não está endemoniado, não existe nele a presença do Demônio. (...) Conheço muitos casos de pessoas que são feridas nos afetos: não encontram mulher ou marido, rompem casamentos e noivados sem qualquer razão; ou ainda, pessoas golpeadas em seus bens: por exemplo, industriais que, de repente, cometem erros descomunais, de tal porte que caem na miséria, ou que sem motivo ficam na rua, assim como muitos casos de comerciantes e artesãos, cujos estabelecimentos muitíssimos bem encaminhados não são mais visitados por ninguém (...). (AMORTH, 2013, p. 27-28)

Ademais, vários santos foram acometidos por vexações diabólicas. Certamente, Santa Gemma Galgani foi a santa, cujas experiências intensas com as vexações mais provocaram sequelas e enfermidades.

Vale ressaltar que só é possível atestar de forma inequívoca que se trata de uma vexação por meio do exorcismo. Para a libertação desse malefício, Amorth frisa a necessidade de colaboração, uma vez que a pessoa acometida deve se abster e afastar-se de práticas perigosas. Depois, se faz necessário avaliar o aspecto espiritual, como avaliações concernentes às práticas de oração, participação nos sacramentos, vida virtuosa e exercício da caridade. Recomenda-se, assim, a confissão, ir à Missa, comungar e celebrar a Adoração Eucarística, rezar o terço, realizar orações como o Pai-Nosso e meditar constantemente sobre as verdades do Evangelho. A maioria das pessoas que sofrem com distúrbios de vexação apenas precisam reencontrar a fé.

Entretanto, quando vemos pessoas devotas e até mesmo santas sofrerem com tais distúrbios, demonstra-se viável a realização de sessões de exorcismo. Contudo, 
alguns santos são acometidos pelas vexações por Providência Divina, mas oferecem, num grandioso ato de amor, seus sofrimentos a Deus, pela conversão dos pecadores. Amorth $(2018, p .76)$ comenta que às vezes o Senhor permite que alguém seja afligido pro vexações diabólicas diretas do Demônio sem que houvesse nenhuma falha grave ou pecado mortal da parte da pessoa acometida.

Por fim, três são as causas das vexações e infestações, sendo elas: permissão divina, o malefício compreendido enquanto um ato de fazer mal a uma pessoa valendo-se de um ser demoníaco e um pedido explícito que se manifesta do pacto com Satanás, que conduz a dependência demoníaca.

\subsection{OBSESSÃO E POSSESSÃO}

A obsessão refere-se a uma ação extraordinária do demônio, cujo aspecto primordial consiste em sujeitar a pessoa a pensamentos obsessivos, nefastos, funestos e com conteúdo que destoam da santidade e das virtudes infusas. Padre Amorth define essa ação extraordinária:

A obsessão ocorre quando uma pessoa é acometida por pensamentos obsessivos, invencíveis, dos quais não consegue, absolutamente, libertar-se nem desviar-se e os quais a levam sempre mais ao desespero e, nos casos extremos, ao suicídio. Infelizmente, este último é um dos resultados que o demônio se propõe a obter como destruidor, também nas outras formas, mas especialmente nos casos de obsessão, nos quais com frequência a pessoa é impelida ao desespero e, portanto, ao desejo ou à tentativa de tirar a própria vida. (AMORTH, 2013, p. 29)

A obsessão não se confunde com a tentação, porquanto a primeira é mais forte, sensível, clara e inequívoca do que a segunda. Na tentação, nunca se tem certeza de que está diante de uma ação do demônio, contudo o mesmo não ocorre na obsessão, cuja ação demoníaca é perceptível, não havendo margem para dúvida. Geralmente, as obsessões atingem pessoas mais santas.

A diferença entre tentação e obsessão consiste no fato de que a segunda é mais clara que a primeira. Por isso, comparativamente, é possível dizer que a natureza da obsessão é mais próxima da tentação que da possessão, pois, tanto uma quanto a outra objetivam levar a pessoa ao 
pecado, mas ela continua livre. (...) A obsessão é algo típico dos santos (...) Obsessões que esses grandes santos sofreram - com permissão divina -, mas que de alguma forma ajudam a mostrar o seu grande valor e mérito.[9]

A obsessão pode ser interna ou externa. O primeiro tipo acomete as potências superiores, especialmente a imaginação. O demônio não apresenta acesso direto à vontade e à inteligência, mas procura atingi-las através das faculdades mais periféricas da alma que estão em contato com o corpo, como a fantasia e a memória. Sendo assim, os ataques costumam envolver imagens obscenas, tentações sexuais disparatas e repugnância pelas coisas divinas. A obsessão externa consiste nas insídias do maligno em promover terror aos sentidos externos. Nela, a pessoa pode ser atacada por visões e aparições diabólicas agradáveis (no sentido de atraírem a vontade ao pecado) ou repugnantes (com o intuito de amedrontar a alma). Santa Gemma Galgani, Santo Antão, Santa Catarina de Sena e São João Maria Vianney sofreram imensamente com esse tipo de investida satânica.

A permissão divina, a inveja do diabo em relação aos filhos de Deus e a imprudência da pessoa obsessionada são algumas causas explicativas acerca desta ação extraordinária.

A origem da obsessão, em primeiro lugar, como foi dito, é a permissão divina, posto que Satanás não possui nenhum poder ordinariamente. Tal como no Livro de Jó, em que o demônio pede a permissão de Deus para testá-lo e Deus a concede. Em segundo, é o fato de que o demônio tem inveja dos filhos de Deus. E a psicologia demoníaca ensina que eles jamais verão a Deus, enquanto homem é vocacionado, chamados por Deus à sua presença. Isso é intolerável para ele. Da mesma forma, a Ave Maria é uma arma terrível contra a ação satânica pois ele não suporta saber que Maria, pequena criatura é "cheia de graça", enquanto ele, anjo de luz, está na desgraça. A inveja é manifesta e inextinguível. A terceira causa pode ser a imprudência da pessoa obsessionada. Ela pode ter provocado ou subestimado a ação satânica, o que uma pessoa humilde jamais faria.[10]

A predisposição natural do obsessionado é outro grande fator, ou seja, pessoas extremamente sensíveis e propensas a alucinações tendem a sofrer os impactos das tentações como obsessões. Sendo assim, os ataques ordinários são sentidos como se fossem extraordinários, uma vez que a pessoa já apresentava fragilidades 
psicológicas. Entretanto, muita cautela e prudência são necessárias para distinguir casos de obsessão de histerias e psicoses.

Água benta, medalhas de São Bento, medalhas de Nossa Senhora, sal e água exorcizados e bentos são excelentes instrumentos no combate às obsessões. Pequenos exorcismos e orações de libertação também são de grande ajuda, contudo, devem ser feitos de forma discreta, com devoção e humildade.

Por fim, a última ação extraordinária consiste na possessão. Padre Fortea a define da seguinte maneira:

A possessão é o fenômeno pelo qual um espírito do mal reside em um corpo e em determinados momentos pode falar e se mover por meio desse mesmo corpo, sem que a pessoa possa evitá-lo. O espírito do mal não reside na alma, permanecendo esta livre e incapaz de ser possuída. Apenas o corpo é suscetível de possessão. (FORTEA, 2010, p.145)

Portanto, a possessão não exclui completamente a liberdade humana, que é preservada por Deus, nem representa o meio mais eficaz do demônio para afastar as almas do Criador, uma vez que a tentação significa o consentimento do homem na prática do pecado. O Padre António Royo Marín ensina, em sua obra "Teología de la Perfección Cristiana", que são quatro os pontos necessários para esclarecer o fenômeno da possessão. São eles:

- Existência da possessão: Existem nas Escrituras uma notável quantidade de relatos acerca dos casos de possessão e de libertação por Cristo. Ademais, várias são as descrições dos santos que enfrentaram esse fenômeno. Considerando que Jesus nunca erraria em matéria tão séria quanto a ação do demônio e também tendo em mente a inerrância das Escrituras em conteúdo espiritual, a possessão é uma realidade na teologia espiritual cristã.

- Natureza da possessão: Nela, o Demônio tem uma atuação desde dentro, ou seja, concentra sua ação no corpo da vítima. Portanto, não se deve pensar que Satanás e seus anjos estão presos a um lugar, uma vez que são puramente espirituais, sendo que somente suas ações se resumem a um lugar. São 
características desse fenômeno extraordinário: a presença do demônio no corpo da vítima e seu império despótico sobre ela.

- Sinais da possessão demoníaca: Padre Antônio Marin enumera alguns sinais que evidenciam o fenômeno em questão, tais como- falar línguas estranhas, conhecimento de fatos desconhecidos, sansonismo e força sobre humana. Contudo, nenhuma das evidências aqui mencionadas não constituem uma prova concreta, pois podem ocorrer meramente por fenômenos naturais. É necessária muita prudência para averiguar decididamente sobre a ocorrência da possessão. Portanto, a prudência deve guiar o discernimento, sendo que as primeiras explicações devem levar em conta os fatores naturais bem como esclarecimentos e hipóteses científicas. Padre Amorth (2004, p.98-99) frisa a necessidade de exigir um parecer médico para que o sacerdote possa realizar uma leitura atenta dos relatórios clínicos.

- A causa das possessões diabólicas: São elas- um pedido da própria vítima, um pecado da vítima e a providência divina. Em última instância, todos as causas remetem a Soberania de Deus. Os demônios não podem fazer tudo o que querem, eles estão subjugados pelo poder divino.

O padre Amorth, além de frisar todos os elementos supramencionados, ressalta outro traço marcante da possessão, a saber: a perda temporária da identidade pessoal. Em casos de possessão, o exorcismo demonstra-se necessário. Exorcismo nada mais é do que um sacramental, uma oração que tem por aspecto teleológico interpelar o demônio para que seja expulso de uma pessoa possessa. O código de Direito Canônico estabelece que ninguém pode legitimamente exorcizar os possessos, a não ser com licença expressa do Ordinário do lugar, ou seja, tal licença deve ser delegada e concedida a um presbítero piedoso, humilde, prudente e devoto. O exorcismo é prova final para averiguar a possessão.

Padre Amorth frisa alguns pontos centrais a serem levados em consideração sobre o exorcismo, tais como: o exorcista age em nome de Jesus Cristo; a força do exorcista é unida a autoridade que recebeu da Igreja; a invocação do nome de João Paulo II é de grande ajuda na realização dos exorcismos e, por fim, a necessidade de a pessoa 
acometida por possessões de pedir perdão a Deus se demonstrou envolvimento com ocultismo, bruxaria e esoterismo.

A conclusão primordial dos escritos demonológicos consiste no fato de que os exercícios da piedade prática e de caridade são os verdadeiros remédios contra a ação demoníaca. Conforme ressaltava o cardeal Ratzinger:

O mistério da iniquidade está inserida na perspectiva cristã fundamental, ou seja, a partir da perspectiva da ressurreição de Jesus Cristo e vitória sobre o poder do mal. Nessa ótica, a liberdade do Cristão e sua tranquila confiança que rechaça o medo toma toda sua dimensão: a verdade exclui o medo, assim permite conhecer o poder do Maligno. (RATZINGER, 1981, p. 160)

Enfim, Amorth frisa que os meios centrais para combater e vencer as possessões residem em quatro práticas: oração, jejum, fé e confiança plena na misericórdia de Cristo. "Pois, se este Senhor é poderoso, como vejo e sei que é, e se os demônios são seus escravos (e disto não há que duvidar, pois é de fé), sendo eu serva deste Senhor e Rei, que mal podem eles fazer a mim?" (TERESA DE JESUS, 1986, p.2005).

A confiança na Providência de Deus, a humildade e a perseverança no exercício dos mandamentos e conselhos de Cristo são imprescindíveis para uma vida espiritual centrada na santidade, compreendida enquanto um verdadeiro remédio contra a influência das tentações e das ações extraordinárias do demônio. Uma vida virtuosa e próxima da graça eficaz de Deus afasta categoricamente as ações demoníacas.

\section{CONSIDERAÇÕES FINAIS}

O estudo acerca das ações diabólicas se faz extremamente necessário para o fomento de uma cosmovisão cristã mais próxima dos elementos primordiais e fundantes das Sagradas Escrituras, bem como dos pressupostos da tradição da Igreja. Uma compreensão correta sobre a natureza do demônio e de suas ações favorece uma visão mais abrangente da teologia dogmática, especialmente da cristologia. Reconhecer o papel e a finalidade da obra de Cristo implica no reconhecimento de sua luta contra Satanás. Sendo assim, a demonologia é de grande 
valor para o fortalecimento da esperança cristã por meio do fomento de uma correta compreensão sobre a obra redentora de Cristo e de sua vitória sobre e escravidão do pecado.

Nesse sentido, o Padre Amorth contribuiu imensamente para a espiritualidade do cristianismo, frisando a eminência dos estudos demonológicos e sintetizando o conteúdo oriundo de suas experiências com libertações de vexações, obsessões e possessões. Os escritos de Amorth seguem a linha doutrinária da patrística, dos estudos de São Tomás de Aquino e dos concílios ecumênicos da Igreja católica, tais como: IV Concílio de Latrão, Concílio de Trento, Concílio Vaticano I e Concílio Vaticano II. Ademais, as obras desenvolvidas pelo exorcista e padre italiano são de grande valia para todos aqueles que procuram uma introdução panorâmica sobre demonologia, ações diabólicas, possessões e libertação.

O padre Amorth sempre era categórico na afirmação da importância de uma cosmovisão cristológica nas batalhas espirituais. No final das contas, o estudo sobre os demônios deve fortalecer a esperança na vitória de Cristo e em sua obra redentora, cujo conteúdo e eficácia desmembraram o poder de Satanás.

Portanto, os dogmas de fé concernentes a existência dos demônios e de suas ações sobre os homens devem ser interpretados a partir da obra redentora de Jesus, para que a fé dos fiéis na Providência de Deus e em sua infinita misericórdia seja renovada e fortalecida pela esperança da vida eterna e dos consolos dos méritos de Cristo. Eis a grande finalidade dos escritos do Padre Amorth acerca de demonologia.

\section{REFERÊNCIAS}

AMORTH, Gabriele. Exorcistas e Psiquiatras. Apelação-Portual: Paulus, 2004.

Não te deixes vencer pelo mal: as palavras de um grande exorcista. Campinas, SP: Ecclesiae, 2018.

. Vade retro, Satanás! . 5.ed. Cachoeira Paulista. SP: Editora Canção Nova, 2013. 
AQUINO, Tomás de. Suma Teológica. São Paulo: Ed. Loyola, 2005. Volume 2.

Suma Teológica. São Paulo: Loyola, 2002.

AZEVEDO JÚNIOR, Paulo Ricardo. A existência do demônio. Disponível: https://padrepauloricardo.org/aulas/a-existencia-do-demonio.

A obsessão demoníaca e suas formas. Disponível em: https://padrepauloricardo.org/aulas/a-obsessao-e-suas-formas.

A reflexão de Santo Tomás de Aquino sobre a ação demoníaca. Disponível em: https://padrepauloricardo.org/aulas/o-doutor-angelico-e-suaimportante-reflexao-sobre-a-acao-demoniaca.

São Miguel, príncipe da humildade. Disponível em: https://padrepauloricardo.org/aulas/sao-miguel-principe-da-humildade.

BAMONTE, Francesco. Possessões diabólicas e exorcismo. São Paulo: Ave Maria, 2004.

BEEKE, Joel. Lutando contra Satanás: conhecendo suas fraquezas, estratégias e derrota. Campina Grande, PB: Visão Cristã, 2018.

BÍBLIA. A Bíblia de Jerusalém. São Paulo: Paulus, 2004.

Catecismo da Igreja Católica. São Paulo: Loyola, 2005.

FORTEA, Jose Antonio. Summa Daemoniaca. São Paulo: Palavra \& Prece, 2010.

MAZZALI, Alexandre. Demonologia e Psiquiatria: do real ao imaginário. Campinas, SP: Eclessiae, 2017.

RATZINGER, Joseph. "Despedida do Diabo?” In: Revista de Cultura Bíblica. São Paulo: Loyola, 1981. Ano 24, v.5, n.17 e 18, p.160.

. Jesus de Nazaré. São Paulo: Ed. Planeta, 2007. vol. I. 
SANTA TERESA DE JESUS. O livro da Vida. 2.ed. São Paulo: Paulinas, 1986.

SANTA TERESINHA DO MENINO JESUS. História de uma alma: Manuscritos autobiográficos. São Paulo: Editora Loyola, 1996.

SAYÉS, José António. O Demónio: realidade ou mito? . Apelação- Portugal: Paulus, 1999.

\section{APÊNDICE - REFERÊNCIAS DE NOTA DE RODAPÉ}

2. AZEVEDO JÚNIOR, Paulo Ricardo. São Miguel, príncipe da humildade. Disponível em: https://padrepauloricardo.org/aulas/sao-miguel-principe-dahumildade. Acessado em 07/06/2020.

3. AZEVEDO JÚNIOR, Paulo Ricardo. A existência do demônio. Disponível: https://padrepauloricardo.org/aulas/a-existencia-do-demonio. Acessado em 07/06/2020.

4. Catecismo da Igreja Católica, Edição revisada de acordo com o texto oficial em latim, 9a edição.

5. AZEVEDO JÚNIOR, Paulo Ricardo. A reflexão de Santo Tomás de Aquino sobre a ação demoníaca. Disponível em: https://padrepauloricardo.org/aulas/o-doutorangelico-e-sua-importante-reflexao-sobre-a-acao-demoniaca. Acessado em 08/06/2020.

6. SANTA TERESINHA DO MENINO JESUS. História de uma alma: Manuscritos autobiográficos. São Paulo: Editora Loyola, 1996.

7. AZEVEDO JÚNIOR, Paulo Ricardo. São Miguel, príncipe da humildade. Disponível em: https://padrepauloricardo.org/aulas/sao-miguel-principe-dahumildade. Acessado em: 11/06/2020.

8. Catecismo da Igreja Católica, Edição revisada de acordo com o texto oficial em latim, 9ª edição. São Paulo: Editora Loyola 
9. AZEVEDO JÚNIOR, Paulo Ricardo. A obsessão demoníaca e suas formas.

Disponível em: https://padrepauloricardo.org/aulas/a-obsessao-e-suas-formas. Acessado em: 16/06/2020

10. Ibidem

Enviado: Junho, 2020.

Aprovado: Agosto, 2020. 